\title{
A REVIEW OF MODELS FOR ASSESSING CARBON STOCKS AND CARBON SEQUESTRATION IN OIL PALM PLANTATIONS
}

\author{
IAN E HENSON*
}

\begin{abstract}
Reliable estimates of the carbon present in stands of oil palm, both in the palms themselves and in other biomass components of oil palm plantations, are crucial for assessing the net greenhouse gas (GHG) balance and carbon footprint of palm oil production. Carbon sequestered during the growth of the oil palm crop generally represents the largest item of the oil palm GHG budget, being second in magnitude only to land use change (LUC) or, for crops grown on peat soil, to microbial peat oxidation. In this article, alternative models available for assessing carbon stocks and carbon sequestration in oil palm plantations are examined taking into account factors such as palm age, planting density and soil type. Both linear and non-linear models are discussed and the crop and plantation components contributing to them are reviewed, as is the methodology used, which may involve destructive or non-destructive techniques, or a combination of both. Guidance is given for selecting the most appropriate model.
\end{abstract}

Keywords: oil palm biomass, growth models, carbon stock, plantation components.

Date received: 23 July 2015; Sent for revision: 8 December 2015; Received in final form: 15 April 2016; Accepted: 29 August 2016.

\section{INTRODUCTION}

Estimating carbon sequestration by the oil palm crop and by other components of oil palm plantations is a major step towards determining the greenhouse gas (GHG) balance of palm oil production. Such estimates, normally carried out annually and ideally throughout the life of the crop, form a crucial part of palm oil GHG accounting but one that has proved to be the most controversial and difficult to assess by the producer. This is partly due to the substantial amount of work involved in making the necessary measurements and in determining the most appropriate methods for doing this. This article reviews the methodology available and provides guidelines for selecting the most appropriate model from a variety of alternatives.

Amberwood House, 6 Beaufort Road, Clifton, Bristol BS8 2JZ, United Kingdom.

E-mail: iehenson@hotmail.com
The grower has the choice of carrying out his own measurements or using existing models that have been identified as providing realistic estimates for a particular plantation or estate. A reliable model is one that gives good correspondence between in situ measurements and model output. Measurements on the standing crop are highly desirable if not essential for assessing selected models but once this has been done and a model has been verified it can be used to generate missing data as well as to extrapolate results to give a full accounting of growth throughout the life of a crop.

Available models can be classified according to the following attributes:

- models giving palm and plantation biomass as a function of palm or plantation age; and

- models relating palm or plantation biomass to some easily measured attribute such as trunk height.

Methods used may involve destructive or nondestructive measurements and may differ in their 
scope and degree of detail. Thus, e.g. only the palms themselves may be assessed and other plantation components ignored or all components may be included. In the case of the palms, many studies consider above-ground biomass only and ignore roots and other below-ground components.

\section{CONSTRUCTING OIL PALM GROWTH CURVES FROM POOLED DATA}

There are numerous examples in the literature of oil palm biomass assessments for palms of different ages but the majority of such data have generally been poorly replicated and both the age range covered and the measurements made have generally been incomplete. To overcome or at least minimise these deficiencies, data obtained from some 34 sources relating biomass to palm age were pooled as shown in Figure 1. This procedure revealed a non-linear trend in biomass versus palm age with increases in biomass with age gradually diminishing over time. One problem with this approach has been the paucity of data for old palms (i.e. those above 20 or so years in the field).

For comparative purposes, Figure 1 also includes data produced by a 'vigorous growth' version of the Oil Palm Production Simulator (OPRODSIM) growth simulation model (Henson, 2005). OPRODSIM is a physiologically based mechanistic model that simulates basic growth processes resulting in biomass values for the main oil palm components such as roots, fronds and trunk. It can be seen that the data generated by OPRODSIM yield a non-linear curve located approximately mid way between the extreme values given by the assorted data obtained in the field.

Some examples where data produced by the OPRODSIM model closely match those obtained by field measurements can be found in Henson (2009c) and others are shown in Figure 2. Both the total standing oil palm biomass and the biomass of individual palm components (fronds and trunk) are well simulated in these cases.

A comparison was also made between the oil palm above-ground standing biomass curve obtained using OPRODSIM and a similar curve produced by Germer and Sauerborn (2008) based on the latter's review of the literature covering 51 plantings and 12 studies. As shown in Figure 3, both curves resulted in a very similar time-averaged standing biomass present over 30 years of 63.62 and $66.77 \mathrm{t} \mathrm{ha}^{-1} \mathrm{yr}^{-1}$; equivalent respectively to 28.63 and $30.0 \mathrm{t}$ carbon $(\mathrm{C}) \mathrm{ha}^{-1} \mathrm{yr}^{-1}$ assuming a $45 \% \mathrm{C}$ content.

\section{Possible Causes of Non-linear Biomass Accumulation}

Non-linear growth patterns such as those involving declines in standing biomass towards the end of the life of a plantation (e.g. Figure 1), are simulated by the OPRODSIM model (Figure 2 ), and can be accounted for by several processes. These include the belated shedding of frond bases (which are otherwise left attached to the trunk for several years after bunch harvest and frond pruning

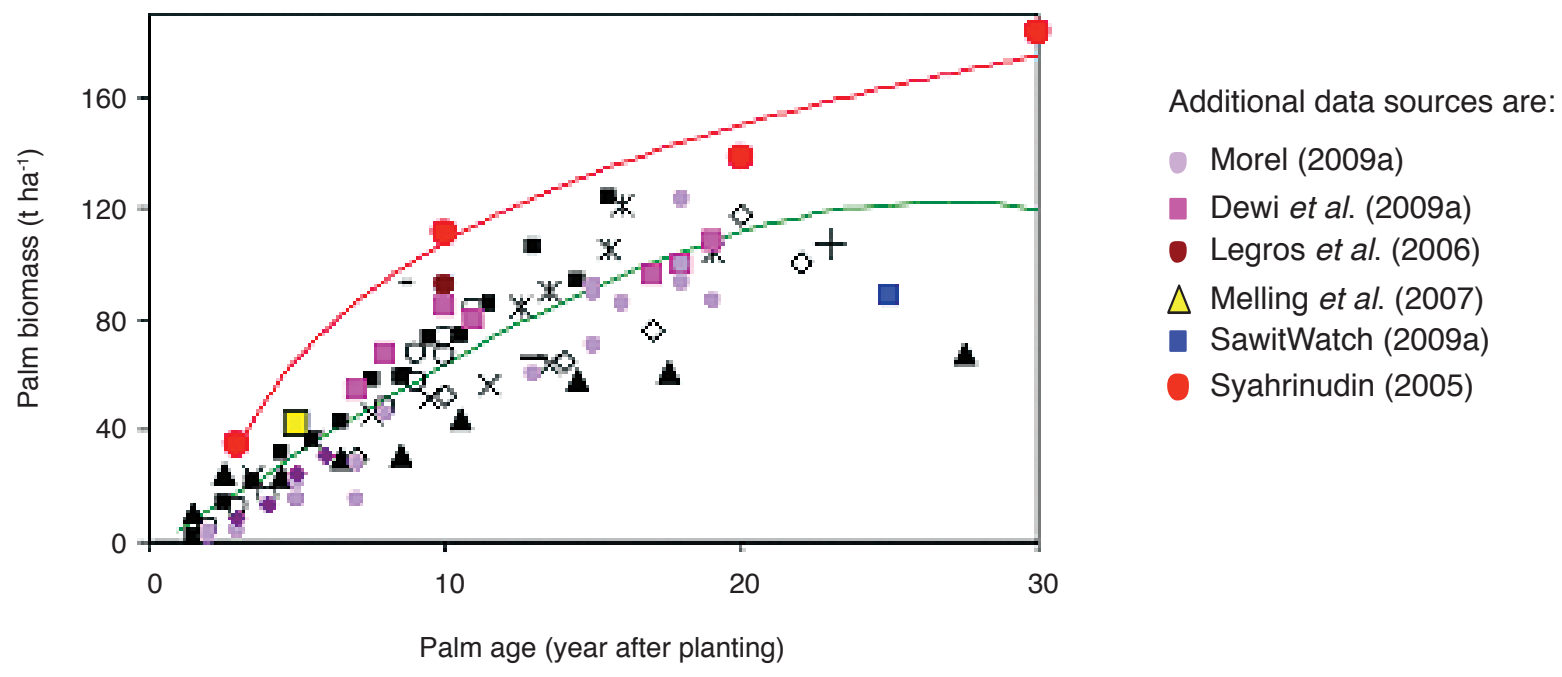

Figure 1. Standing biomass of oil palm stands of different ages.

Note: Data represented by black and white symbols are reproduced from Henson (1999; 2009d). Other data, represented by coloured symbols, were obtained from newer sources listed below. All measurements include roots or an allowance for roots but exclude minor biomass components such as frond bases left on the trunk after pruning, male inflorescences still attached to the palm, and developing fruit bunches. Where necessary, data were adjusted for differences in planting density using a standard density of 148 palms ha ${ }^{-1}$. The majority of data were obtained by destructive measurements. The green curve was produced using the 'vigorous' growth option of the Oil Palm Production Simulator (OPRODSIM) model (Henson, 2005). The figure is modified from Henson (2009a). 
(a) Oil palm above-ground standing biomass vs. palm age

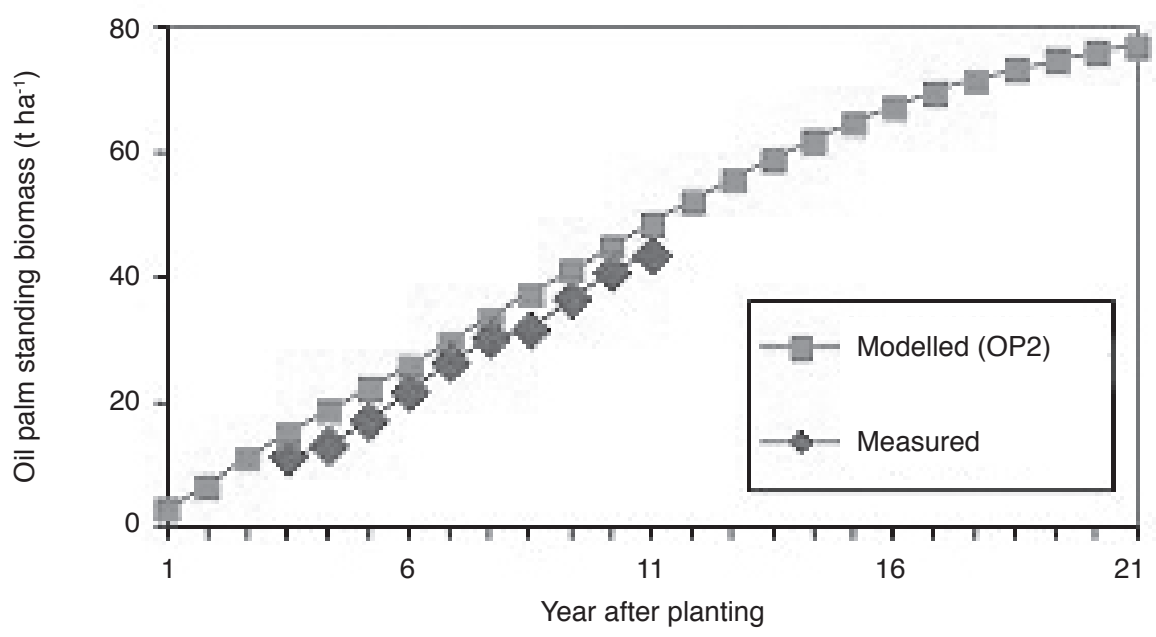

(b)

Oil palm above-ground standing biomass vs. palm age

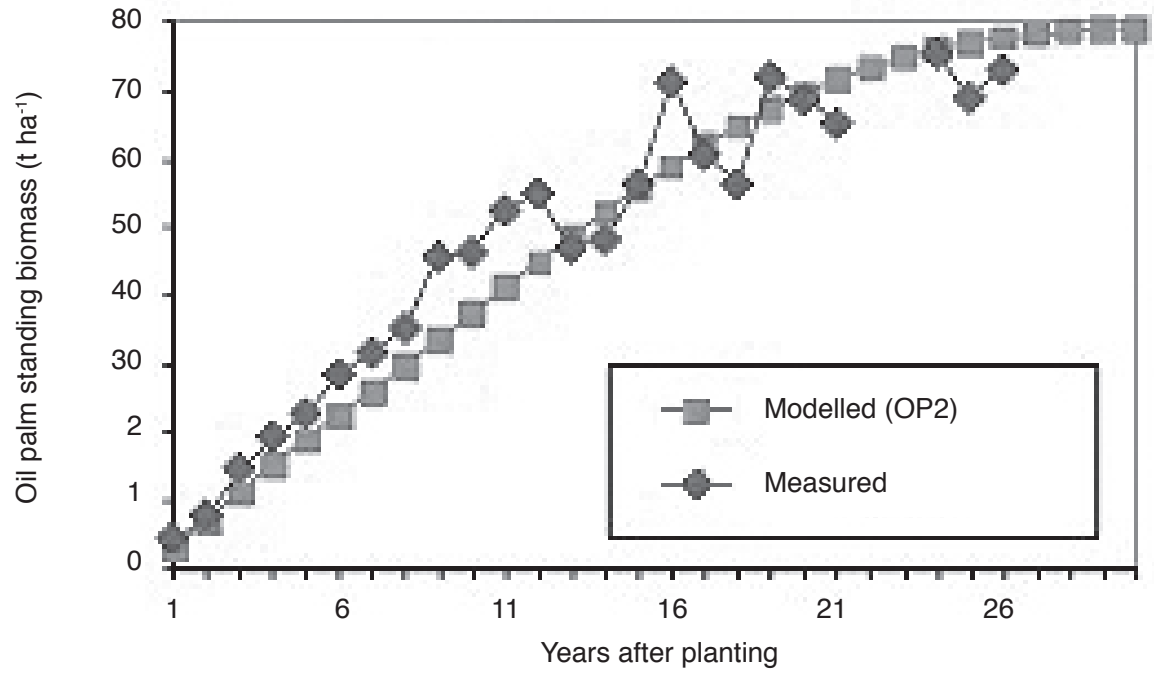

(c)

Oil palm above-ground standing biomass vs. palm age

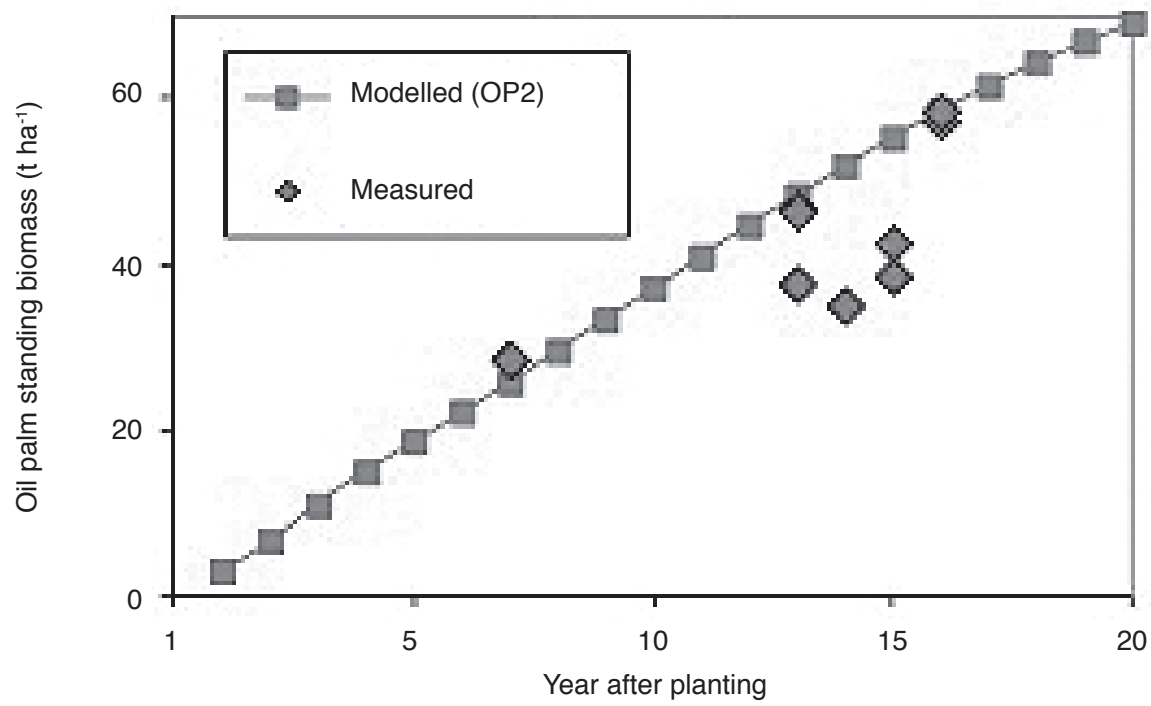

Figure 2. Comparisons between measured and modelled oil palm standing biomass at three sites ( $a, b, c)$. Measured data were obtained using standard non-destructive methods (Corley and Tinker, 2015). Modelled data were obtained using the 'vigorous growth' version of the Oil Palm Production Simulator (OPRODSIM) growth simulation model (OP2) as shown by Chase et al. (2012) and Bessou et al. (2014). 
Oil palm above-ground standing biomass curves

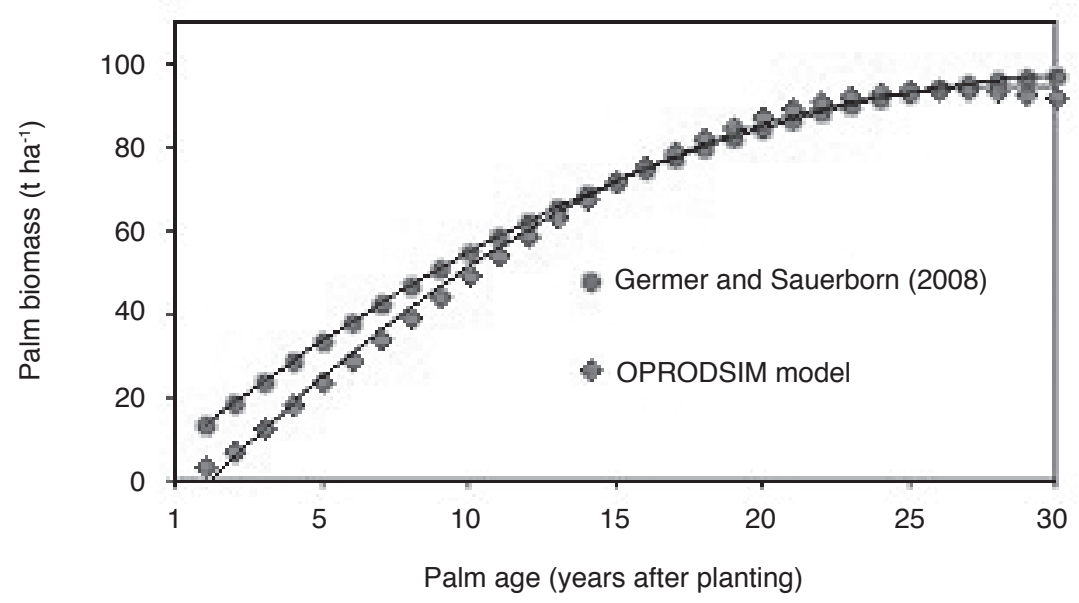

Figure 3. Comparison of two above-ground oil palm biomass curves; one produced using the OPRODSIM model for 'vigorous' growth conditions as shown in Figure 1, and the other based on the literature review of Germer and Sauerborn (2008). The latter figure, with data fitted using polynomial equations, is modified from Henson (2009a).

(Figure 4)), the failure of frond biomass production to fully compensate for the loss of frond biomass due to pruning and harvesting of fruit bunches, to a reduction in standing bunch biomass with palm age, and to the decline and death of old palms due to diseases such as Ganoderma. An example of agerelated shedding of pruned frond bases is shown in Figure 4. Others are given by Henson et al. (2012).

\section{Total Plantation Biomass}

In addition to the oil palms themselves, biomass is also present in the plantation in the form of other components that include ground cover vegetation, pruned frond piles, and plantation litter such as shed frond bases, male inflorescences and residual debri from previous crops or vegetation left over from land clearing for new oil palms (some of which is strictly necromass having undergone various phases of decomposition). As with the palms, these components can either be measured in situ [e.g. Syahrinudin (2005); Khasanah et al. (2012)], or estimated using models. An example of the latter is the OPCABSIM model (Henson, 2009b; 2010), that is designed to complement OPRODSIM by catering for these additional forms of carbon sequestration.

The inclusion of plantation components in addition to the palms themselves (e.g. Figure 5) results in an increase in the standing biomass in the plantation of from $6 \%$ to almost $18 \%$ over a 25 -year lifetime (Henson and Chase, 2010; Khasanah et al., 2012).

Frond base biomass vs. palm age

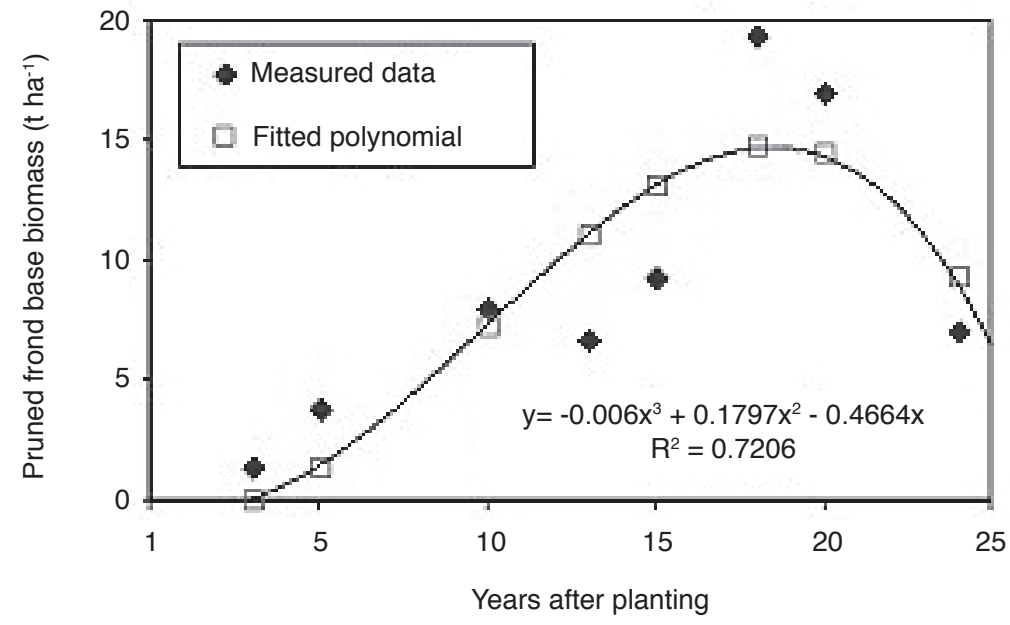

Figure 4. Changes with time in biomass of frond bases adhering to the trunk. Modified from Henson et al. (2012). 
(a)

Oil palm and total plantation biomass vs. palm age

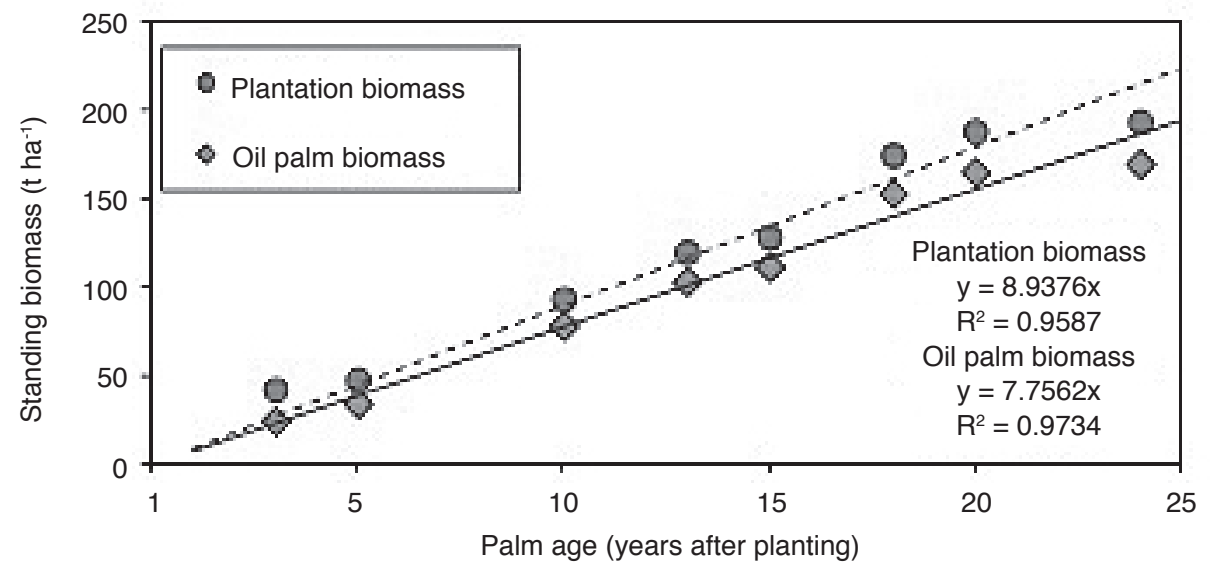

(b)

Oil palm and total plantation biomass vs. palm age

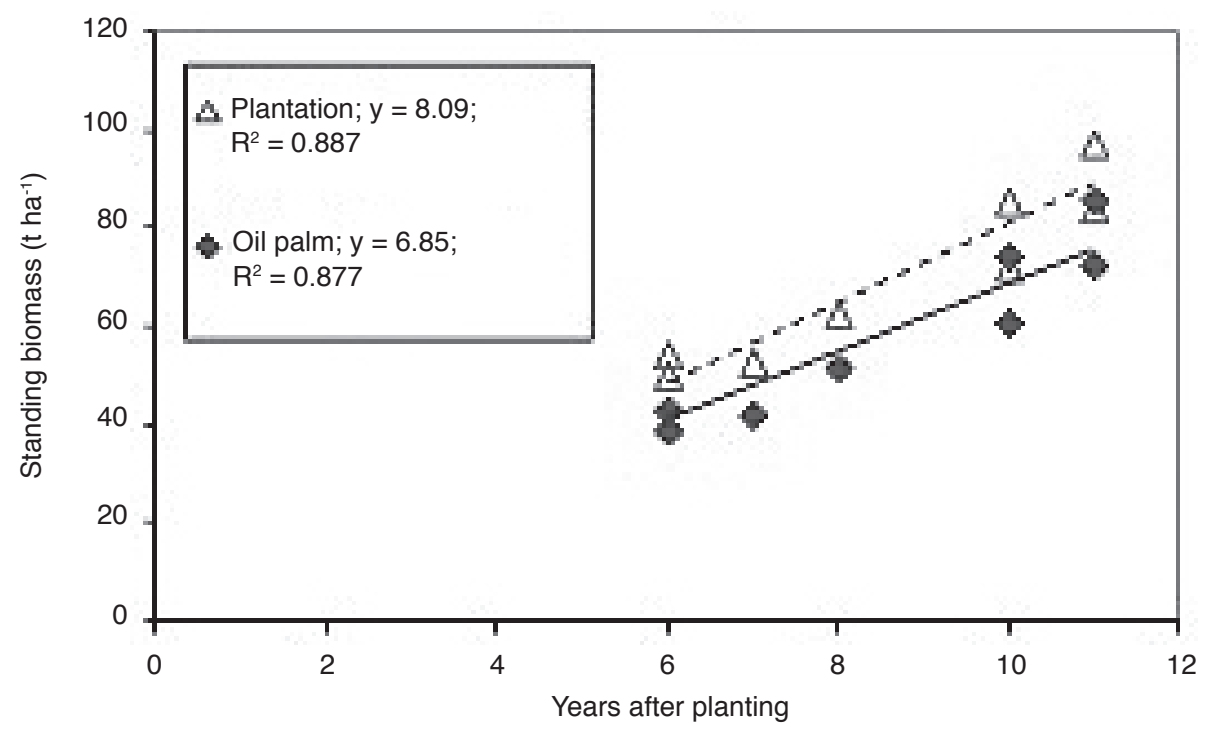

(c)

Oil palm and total plantation biomass vs. palm age

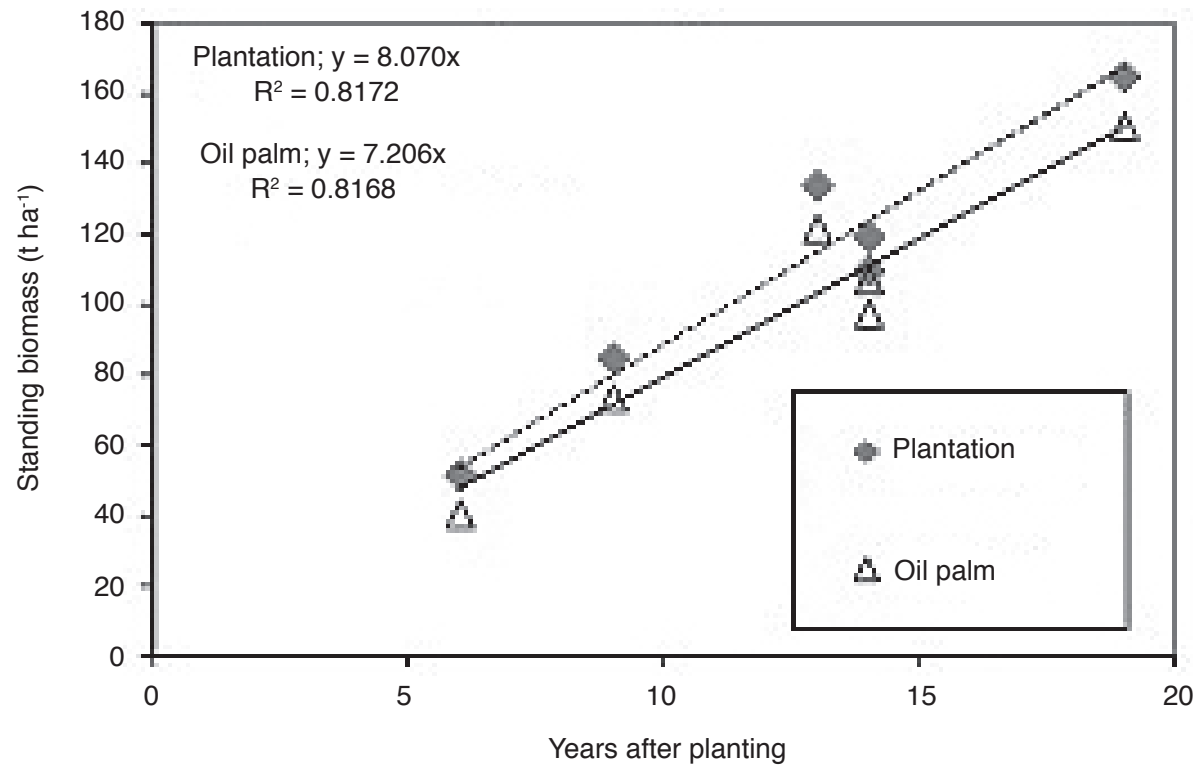

Figure 5. Changes with time in standing biomass of oil palms and other oil palm plantation components as assessed by in situ measurements at several sites $(a, b, c)$ in Papua New Guinea (Henson and Chase, 2010). 


\section{LINEAR $v s$. NON-LINEAR MODELS}

It should be noted that most oil palm growth data exhibit linearity in the early phases of oil palm growth but at this stage the scatter of data can often obscure the actual trend (e.g. Figure 1) and it becomes necessary to examine longer-term records in order to determine if the trend is truly linear. In such cases, linear models provide a good fit to measured data but one that clearly deviates from that predicted using OPRODSIM (e.g. Figure 6).

Studies by the International Centre for Research in Agroforestry (ICRAF, Indonesia) have, for at a large number of sites, resulted in a series of allometric equations relating aboveground palm biomass to palm age and trunk height. Above-ground palm biomass was found to increase linearly with palm age up to at least 27 years after planting (Figure $7 a$ ) with a trunk height increase of up to $14 \mathrm{~m}$ (Figures $7 b$ and $7 c$ ). Only small differences were observed due to soil type such as those between palms on mineral versus peat soils but somewhat larger ones occurring between estate palms and those on smallholdings (the latter being less productive). The actual parameters and the range of the $x$-axes varied with the source of data (van Noordwijk et al., 2010; Khasanah et al., 2012; Harja et al., 2012).

Root biomass of the palms measured by ICRAF was calculated from the above-ground biomass assuming a fixed root:shoot ratio of 0.25 . This is similar to the 30-year mean root:shoot (R:S) value of 0.221 calculated by OPRODSIM for smallholder palms ( $R: S=0.221)$ with average growth, and the ratio of 0.247 generated by OPRODSIM for estate palms with vigorous growth. In view of the paucity of the data, further measurements are desirable for roots, to assess their contribution to total oil palm biomass.

The amounts of carbon in the understory (ground cover, litter and necromass) in the plantations studied by ICRAF were obtained by destructive sampling (Khasanah et al., 2012) and are shown in Table 1. As with most other plantation data, these are time-averaged values that apply assuming either a 25- or 30-year oil palm replanting cycle. In

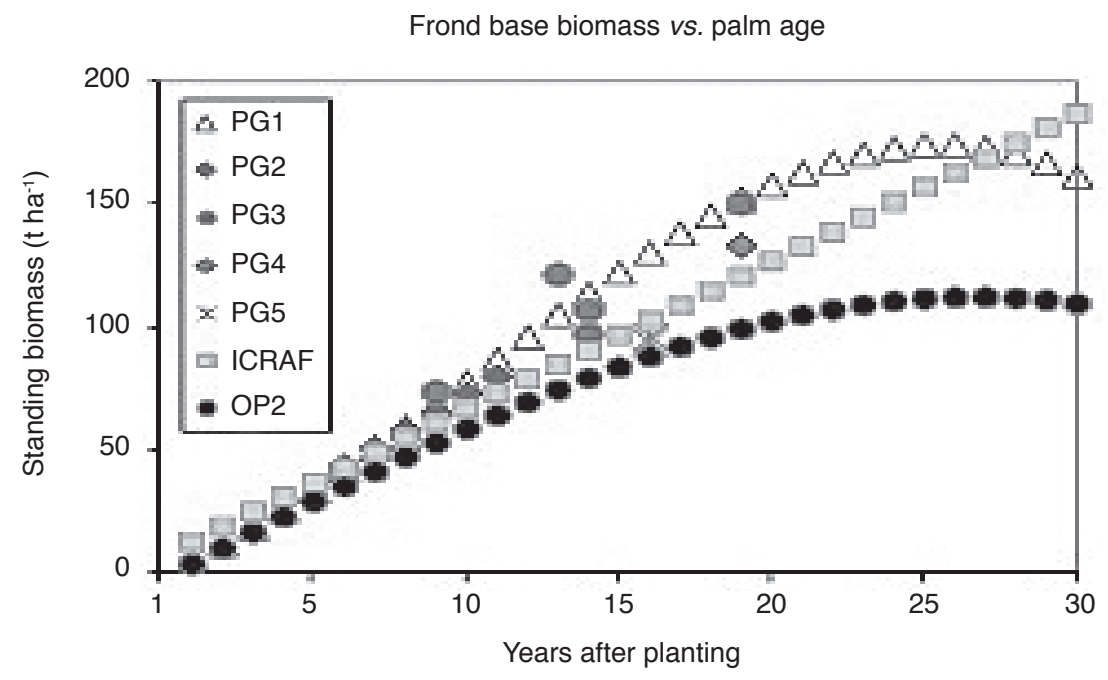

Figure 6. Oil palm biomass measured directly at several sites in Papua New Guinea (PG1 to PG5) compared to biomass simulated using the 'vigorous' growth option of the Oil Palm Production Simulator (OPRODSIM) model (OP2) or to a linear regression of biomass against palm height [Khasanah et al. (2012) for estate palms on mineral soil (ICRAF)].

TABLE 1. OIL PALM PLANTATION BIOMASS COMPONENTS ON EX-FORESTED LAND IN INDONESIA AS ASSESSED BY ICRAF*

\begin{tabular}{|c|c|c|c|c|c|c|c|}
\hline \multirow[t]{2}{*}{ Soil type } & \multirow{2}{*}{$\begin{array}{l}\text { Management } \\
\text { system }\end{array}$} & \multicolumn{6}{|c|}{ Time averaged $\mathrm{C}$ stock ( $\mathrm{t}$ ha $\mathrm{yr}^{-1}$ ) } \\
\hline & & $\begin{array}{l}\text { Oil palm } \\
\text { trunk and } \\
\text { fronds }\end{array}$ & Under-story & Litter & Necro-mass & Roots & Total \\
\hline \multirow[t]{2}{*}{ Mineral } & Estate land & 38.60 & 0.51 & 2.36 & 3.60 & 9.65 & 54.72 \\
\hline & Smallholdings & 33.78 & 0.51 & 2.79 & 3.60 & 8.45 & 49.13 \\
\hline Peat & Estate landings & 34.00 & 0.51 & 2.36 & 3.60 & 8.50 & 48.97 \\
\hline
\end{tabular}

Note: *Indonesian Centre for Research in Agroforestry. Modified from Table 2 of Khasanah et al. (2012). Values were calculated assuming a 25-year replanting cycle. 
(a)

Palm biomass vs. trunk height

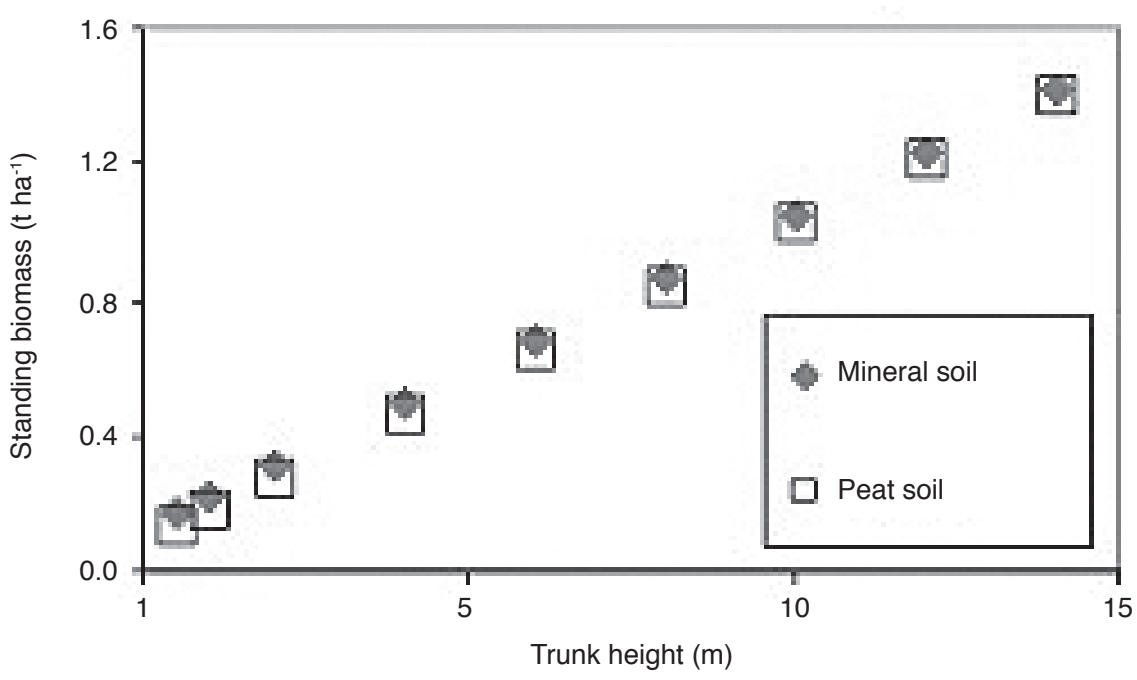

(b)

Palm biomass vs. palm age (1)

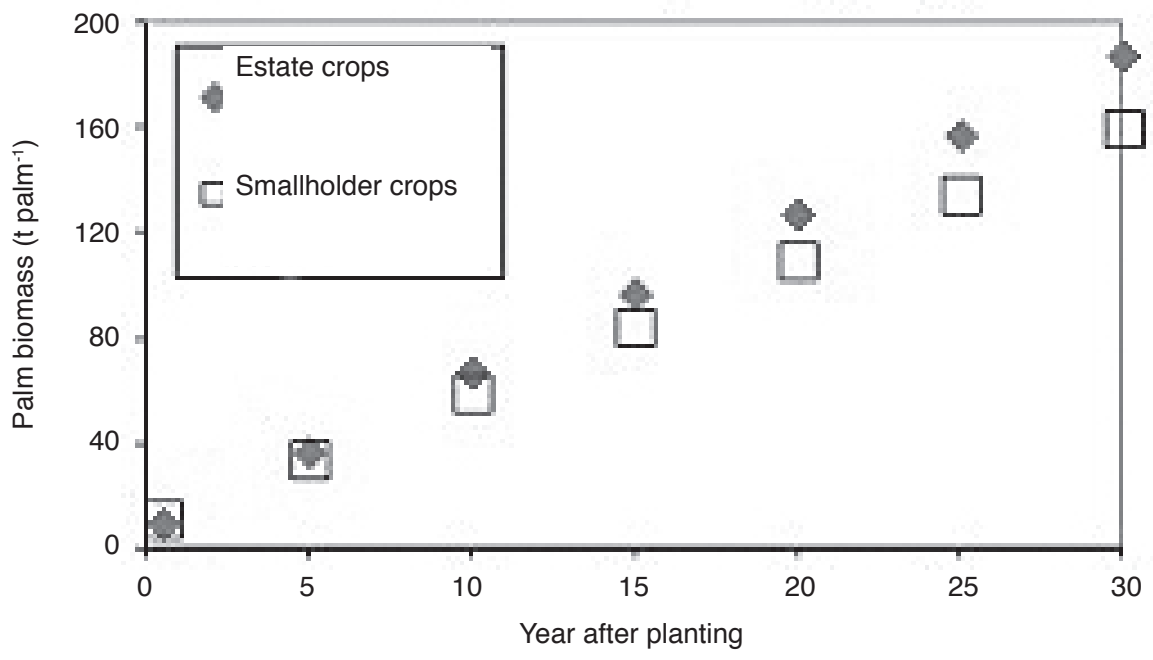

(c)

Palm biomass vs. palm age (2)

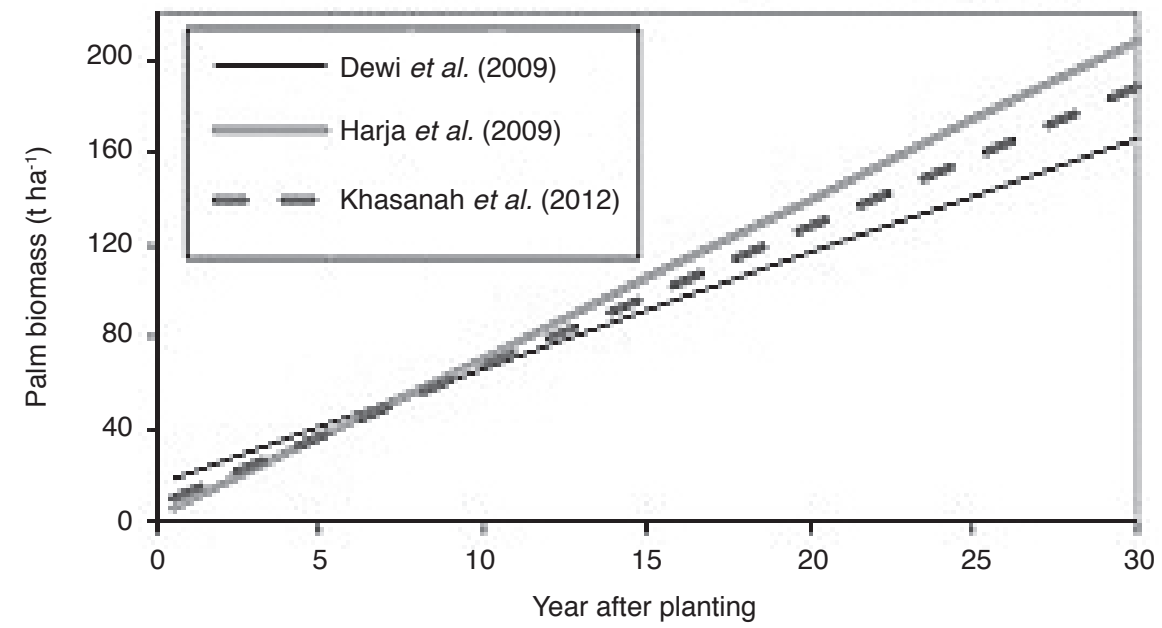

Figure 7. Correlations between (a), above-ground oil palm biomass and trunk height for two soil types, between (b), above-ground oil palm biomass and palm age for two management regimes, and between (c), above-ground oil palm biomass and oil palm age for three data sets. 


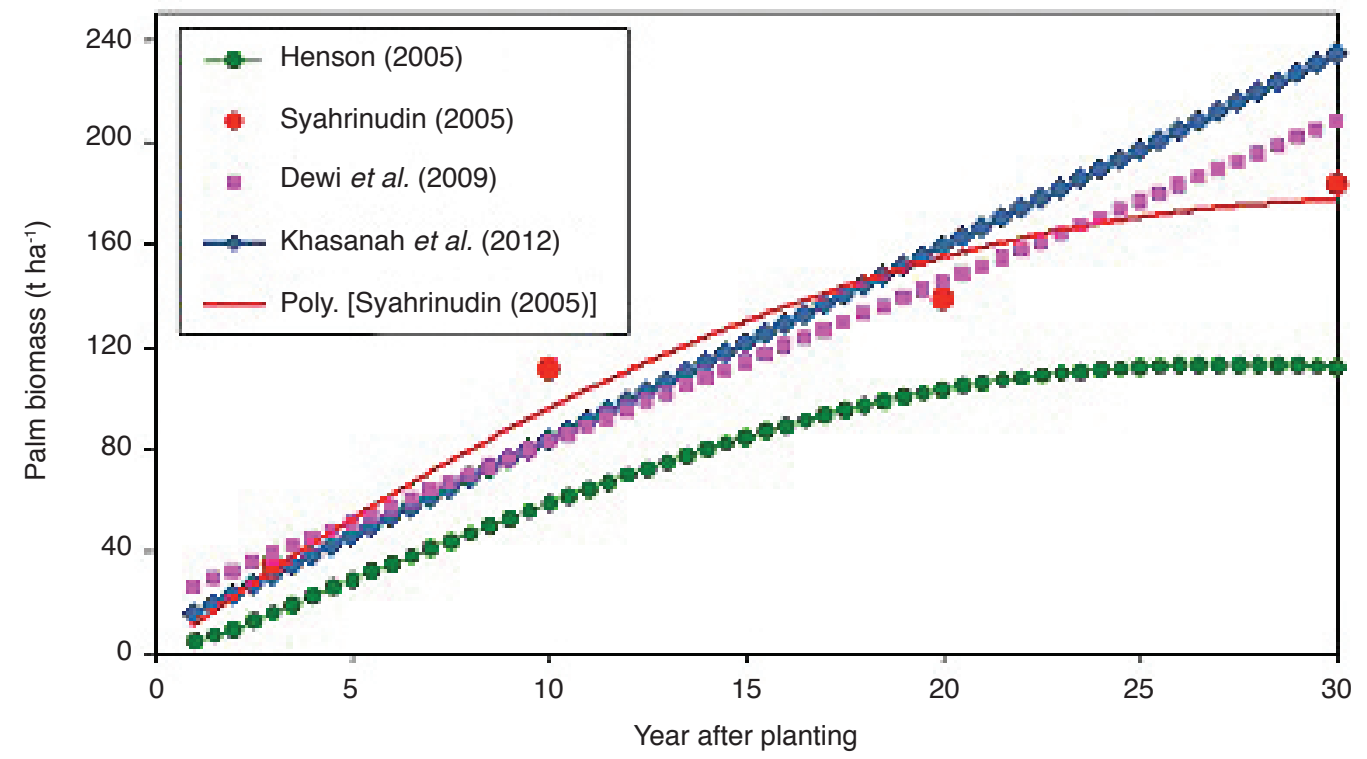

Figure 8. Comparisons between linear and non-linear models of total (i.e. above-and below-ground) oil palm biomass and data obtained by Syahrinudin (2005) using destructive measurements. The green curve (Henson, 2005) was produced using the Oil Palm Production Simulator(OPRODSIM) model.

the case of necromass, this was significant only for sites converted to oil palm from rain forest.

With regard to the above-ground oil palm biomass, no equations comparable to those obtained for estate palms have thus far been obtained for smallholder palms on peat.

Comparisons between both linear and nonlinear models of palm biomass plotted against palm age are shown in Figure 8. The use of the ICRAF equations resulted in substantially greater biomass throughout the life of the plantation than did those using OPRODSIM while destructive measurements undertaken earlier by Syahrinudin (2005) were not too dissimilar from results of ICRAF regressions over the first 20 years. However, after this they exhibited a quite definite non-linear trend.

\section{CONCLUSION}

Several models have been developed to assess biomass production and carbon accumulation by oil palm, leading to estimates of carbon sequestration by the palms as well as by other components of the oil palm plantation such as ground vegetation, residual necromass from vegetation present at the time of planting and palm litter such as frond piles, shed frond bases and male inflorescences. The models available differ in several respects but can be broadly divided into those based on destructive measurements (involving the division of whole palms into major growth components such as fronds, trunk and roots), and non-destructive methods that involve measurements on intact palms with only minimal damage to the standing crop. In addition to minimising crop damage, non-destructive techniques have the important advantage of permitting repeated measurements over time on the same palms. They are also generally less timeconsuming than destructive measurements and result in less variable assessments partly due to a larger number of palms being sampled. On the other hand, destructive sampling leads to more direct and possibly more accurate assessments of biomass of individual palms, especially for the palm root system which is generally only sampled in part when using non-destructive techniques. Detailed descriptions of the measurements undertaken during non-destructive assessments are given by Corley and Breure (1981), Breure and Verdooren (1995) and Corley and Tinker (2015) amongst others.

Destructive sampling is, in any case required for establishing allometric equations relating empirical (non-destructive) measurements to biomass. But once these are established the use of such equations can greatly simplify biomass assessment. The derivation of biomass from palm height or from palm age (e.g. Dewi et al., 2009; Khasanah et al., 2012) are examples of the utility of this approach. Once these relationships are determined they can be readily applied to other oil palm stands with little or no impact on the crop.

There still remains the problem of how to fully assess and include the below-ground biomass and other plantation components such as ground cover and litter that represent additional sites for carbon sequestration by the plantation. Given the variability and poor accessibility of the oil palm root system, assessing roots usually proves to be a difficult and laborious task and inevitably 
involves some degree of destructive sampling such as that typified by excavating trenches or taking soil cores. Fortunately the impact on the crop as a whole of such sampling is generally small with the samples taken usually representing only a minor proportion of the total soil rooting volume. Also, the frequency of sampling over time is low with annual assessments usually being sufficient. Root data obtained from the same palms as the shoot allow root:shoot ratios to be calculated that can be used to predict root biomass from above-ground biomass of other palms. Presently, however, such data are few and more estimates of root biomass are needed to provide better assessments of both root and whole palm biomass.

\section{SUPPLEMENTARY INFORMATION}

Supplementary information on the models can be found in MS Excel file: PalmGHG Crop seq options July 2015 via http://jopr.mpob.gov.my/wpcontent/uploads/2017/03/palmGHG.xls, which contains data from the following sources:

1. Oil palm database;

2. Database references;

3. Oil palm models;

4. ICRAF linear models

\section{ACKNOWLEDGEMENT}

I am most grateful to several palm oil producing companies for generously supplying data used in the construction of the oil palm growth models and to Melissa Chin for helpful advice on the production of the article.

\section{REFERENCES}

BESSOU, C; CHASE, L D C; HENSON, I E; ABDULMANAN, A F N; MILA i-CANALS, L; AGUS, F; SHARMA, M and CHIN, M (2014). Pilot application of PalmGHG, the RSPO greenhouse gas calculator for oil palm products. O J. Cleaner Production, 73: 136-145.

BREURE, C J and VERDOOREN, L R (1995). Guidelines for testing and selecting parent palms in oil palm. Practical aspects and statistical methods. ASD Oil Palm Papers, 9: 1-68.

CHASE, L D C; HENSON, I E; ABDUL-MANAN, A F N; AGUS, F; BESSOU, C; MILA i-CANALS, L and SHARMA, M (2012). PalmGHG: the RSPO Greenhouse Gas Calculator for Oil Palm Products, Beta-version. The Roundtable for Sustainable Palm Oil - RSPO, Kuala Lumpur, Malaysia. 57 pp.
CORLEY, R H V and BREURE, C J (1981). Measurements in Oil Palm Experiments. Internal report. Unilever Plantations Group. 33 pp.

CORLEY, R H V and TINKER, P B (2015). The Oil Palm. $5^{\text {th }}$ ed. Blackwell Scientific, Oxford.

DEWI, S; KHASANAH, N; RAHAYU, S; KADINATA, A and VAN NOORDWIJK, M (2009). Carbon Footprint of Indonesian Palm Oil Production: a Pilot Study. World Agroforestry Centre - ICRAF, SEA Regional Office, Bogor, Indonesia. 8 pp.

GERMER, J and SAUERBORN, J (2008). Estimation of the impact of oil palm plantation establishment on greenhouse gas balance. Environment, Development and Sustainability, 10: 697-716.

HARJA, D; KHASANAH, N; AGUS, F and VAN NOORDWIJK, M (2012). Oil Palm Plantation Carbon Stock Calculator. World Agroforestry Centre ICRAFSEA Regional Programme and Indonesian Soil Research Institute.

HENSON, I E (1999). Comparative ecophysiology of oil palm and tropical rain forest. Oil Palm and the Environment. A Malaysian Perspective (Singh, G; Lim, K H; Teo, L and Kow, D L eds.). Malaysian Oil Palm Growers Council, Kuala Lumpur. p. 9-39.

HENSON, I E (2005). OPRODSIM, a versatile, mechanistic, simulation model of oil palm dry matter production and yield. Proc. of the 2005 International Palm Oil Congress - Agriculture Conference. MPOB, Bangi. p. 801-832.

HENSON, I E (2009a). A Note on Assessing the Greenhouse Gas Balance of Palm Oil Production: Quantifying Plantation Carbon Stocks and Carbon Emissions from Peat Land. Report prepared for RSPO Greenhouse Gas Working Group. 10 pp.

HENSON, I E (2009b). Modelling carbon sequestration and greenhouse gas emissions associated with oil palm cultivation and land-use change in Malaysia. A re-evaluation and a computer model. MPOB Technology No. 31: 116 pp.

HENSON, I E (2009c). Modelling Dry Matter Production, Partitioning and Yield of Oil Palm. OPRODSIM. A Mechanistic Simulation Model for Teaching and Research. Technical Manual and Users' Guide. MPOB, Bangi. 92 pp.

HENSON, I E (2009d). Comparative ecophysiology of oil palm and tropical rain forest. Sustainable Production of Palm Oil. A Malaysian perspective (Singh, G; Lim, K H; Teo, L and Chan, K W eds.). Malaysian Oil Palm Growers Council, Kuala Lumpur. p. 1-52. 
HENSON,IE (2010). OPCABSIM. AModelling Package for Estimating Carbon Sequestration, Greenhouse Gas Emissions and Carbon Balance Associated with Oil Palm Production in Malaysia. Technical Manual and User's Guide. MPOB, Bangi. 81 pp.

HENSON, IE and CHASE, LDC (2010). Unpublished data.

HENSON, I E; BETITIS T; TOMDA, Y and CHASE, L D C (2012). The estimation of frond base biomass (FBB) of oil palm. J. Oil Palm Res. Vol. 24: 1473-1479.

KHASANAH, N; VAN NOORDWIJK, $\mathrm{M}$; EKADINATA, A; DEWI, S; RAHAYU, S; NINGSIH, $\mathrm{H}$; SETIAWAN, A; DWIYANTI, E and OCTAVIANI, R (2012). The Carbon Footprint of Indonesian Palm Oil Production. Technical Brief No. 25: Palm Oil Series. Bogor, Indonesia. World Agroforestry Centre ICRAF, SEA Regional Office. 10 pp.

LEGROS, S; MIALET-SERRA， I; CALIMAN, J-P; CLEMENT-VIDAL, A; SIREGAR, F; WIDIDIASTUTI, L; JOURDAN, C and DINGKUHN, M (2006). Carbohydrate reserves in 9 years old oil palm: nature, distribution and seasonal changes. Paper presented at the 2006 International Oil Palm Conference, 19-23 June 2006, Bali.
MELLING, L; GOH $\mathrm{K}$, J; BEAUVAIS, $\mathrm{C}$ and HATANO, R (2007). Carbon flow and budget in a young mature oil palm agroecosystem on deep tropical peat. Presented at the International Symposium and Workshop on Tropical Peatland. International Peat Society, Yogyakarta, Indonesia, 27-31 August 2007. 5 pp.

MOREL, A (2009a). Estimates of Aboveground Biomass Forest and Oil Palm Values for Sabah, Malaysia. Report for the Roundtable on Sustainable Palm Oil (RSPO) Greenhouse Gas Working Group (GHG WG). 9 pp.

SAWIT WATCH, INDONESIA (2009a). Unpublished results.

SYAHRINUDIN (2005). The potential of oil palm and forest plantations for carbon sequestration on degraded land in Indonesia. Ecology and Development Series No. 28: 1-107.

VAN NOORDWIJK, DEWI, S; KHASANAH, N; EJKADINATA, A; RAHAYU, S; CALIMAN, J P; SHARMA, M and SUHARTO, S (2010). Estimating the carbon footprint of biofuel production from oil palm: methodology and results from two pilot areas in Indonesia. Paper presented at the $2^{\text {nd }}$ International Conference on Oil Palm and Environment (ICOPE) 2010. Bali, Indonesia. 